\title{
Research into analgesic effect of ondansetron in persistent pain model in rats with central noradrenergic system lesion
}

\author{
Wojciech Roczniak1, Joanna M. Oświęcimska², Barbara Brodziak-Dopierała³, Elżbieta Cipora1, \\ Przemysław G. Nowak ${ }^{4}$, Magdalena Babuśka-Roczniak ${ }^{1}$ \\ ${ }^{1}$ The Jan Grodek Higher Vocational State School in Sanok, Medical Institute, Poland \\ ${ }^{2}$ Department of Paediatrics, School of Medicine with the Division of Dentistry in Zabrze, Medical University of Silesia, \\ Katowice, Poland \\ ${ }^{3}$ Medical University of Silesia School of Pharmacy with the Division of Laboratory Medicine Department of Toxicology, \\ Sosnowiec, Poland \\ ${ }^{4}$ Toxicology and Drug Addiction Division, Department of Toxicology and Health Protection, Public Health Faculty, \\ Medical University of Silesia, Katowice, Poland
}

Roczniak W, Oświęcimska JM, Brodziak-Dopierała B, Cipora E, Nowak PG, Babuśka-Roczniak M. Research into analgesic effect of ondansetron in persistent pain model in rats with central noradrenergic system lesion. J Pre-Clin Clin Res. 2015; 9(2): 140-144. doi: 10.5604/18982395.1186495

\section{Abstract}

Introduction. Many known substances affecting the serotoninergic system induce definite physiological effects, including those which are therapeutic. For instance, the enhanced serotoninergic transmission due to decreased functions of autoreceptors and increased inhibitory functions of postsynaptic $5-\mathrm{HT}_{1 \mathrm{~A}}$ is associated with antidepressant effect. The central serotoninergic system takes part in the regulation of many bodily functions, such as sleep, wakefulness, blood pressure, pain perception or sexual behaviours. Moreover, it is involved in the pathogenesis of depression, anxiety, addictions, migraine and other headaches. In pain therapy, not only typical analgesics are used, but also substances without obvious analgesic effect, thus allowing potential pharmacological modulation of analgesic activity in the treatment of pain.

Objective. The aim of the study was to determine whether a chemical lesion to the central noradrenergic system at an early stage of individual development alters reactivity of $5-\mathrm{HT}_{3}$ receptors in adult rats.

Materials and method. The study used newborn and adult Wistar rats aged 8-10 weeks. Behavioural tests (writhing test, formalin assay) were used to assess the analgesic action of ondansetron as a 5- $\mathrm{HT}_{3}$ receptor antagonist.

Results. The analgesic effect of ondansetron ( $1.0 \mathrm{mg} / \mathrm{kg}$ b.w., i.p.) in the writhing test was weak and short. Pain intensity score after ondansetron injection (1.0 mg/kg b.w., i.p) was 2-3 points and did not differ significantly between the study groups.

Conclusions. Damage to the central noradrenergic system at an early stage of individual development has no effect on the antinociceptive effects of the serotonin (5-HT3) receptor antagonist, ondansetron, in the persistent pain model.

\section{Key words}

central serotoninergic system, lesion, central noradrenergic system, ondansetron, analgesic effect

\section{INTRODUCTION}

The central serotoninergic system takes part in the regulation of many life functions, such as sleep, wakefulness, blood pressure, pain perception or sexual behaviours. Moreover, it is involved in the pathogenesis of depression, anxiety, addictions, migraine and other headaches. Serotonin (5-hydroxytriptamine, 5-HT) is thought to be the major mood-regulating factor. Even trace amounts of this neurotransmitter affect mood, appetite, sleep and pain tolerance. A drop in its level may cause 'addictive' binge eating, sleeplessness, depression, aggression, low pain tolerance, and impair thermoregulatory mechanisms $[1,2]$. Neuronal bodies of the central serotoninergic system are located mainly in the medial part of the brain stem, in the raphe nuclei (medial dorsal and great nucleus). Their axons form projections ascending to the structures of the striatum, cerebral cortex, cerebellar cortex, hippocampus, amygdala,

Address for correspondence: Wojciech Roczniak, The Jan Grodek Higher Vocational State School in Sanok, Medical Institute, Mickiewicza 21, 38-500 Sanok, Poland E-mail: wojciech_roczniak@interia.pl

Received: 27 August 2015; accepted: 28 September 2015 thalamus, hypothalamus and projections descending to the spinal cord $[3,4]$.

Many known substances affecting the serotoninergic system induce certain physiological as well as therapeutic effects. For instance, enhancement of serotoninergic transmission through decreased functions of autoreceptors and intensification of inhibitory functions of postsynaptic $5-\mathrm{HT}_{1 \mathrm{~A}}$ are associated with antidepressant effect.

In turn, increased function of the autoreceptors or postsynaptic receptors in the limbic system is connected with an anxiolytic effect. Agonists of $5-\mathrm{HT}_{2}$ receptors decrease dopamine secretion and the action of dopaminergic neurons in the limbic system, whereas their antagonists have antipsychotic, anxiolytic and antidepressant effects.

The antagonists of $5-\mathrm{HT}_{3}$ receptors are most frequently used in chemotherapy-induced nausea and vomiting. Their mechanism consists in the blockage of $5-\mathrm{HT}_{3}$ receptors, both peripherally in the endings of the vagus nerve, and centrally in the area postrema, and in the solitary nucleus $[5,6]$.

The $5-\mathrm{HT}_{3}$ receptors located centrally (within the spinothalamic tract, brain stem nuclei, thalamus and posterior horns of the spinal cord) and peripherally (within 
nerve endings of afferent nociceptive fibres) are involved in the process of generation and perception of pain. The peripheral $5-\mathrm{HT}_{3}$ receptors have been shown to take part in pain generation induced by an inflammatory process. However, they have no effect on pain caused by mechanical or thermal stimuli. Tissue-released $5-\mathrm{HT}$, by affecting the peripheral $5-\mathrm{HT}_{3}$ receptors, sensitizes the neurons responsible for the perception of pain caused by bradykinin (pronociceptive effect) $[7,8]$. In turn, the centrally released 5 -HT exerts an antinociceptive effect, e.g. by stimulating $5-\mathrm{HT}_{3}$ receptors. That effect can be blocked by the administration of the central $5-\mathrm{HT}_{3}$ receptor antagonist. In the spinal cord, the $5-\mathrm{HT}_{3}$ receptors can also modulate the function of GABA-ergic interneurons involved in pain perception [9].

\section{OBJECTIVE}

The aim of the study was to determine whether a chemical lesion to the central noradrenergic system in an early period of individual development changes the reactivity of the $5-\mathrm{HT}_{3}$ receptors in adult rats. Behavioural tests (writhing test and formalin assay) and the 5-HT3 receptor antagonist, ondansetron, were used to investigate the function of these receptors

\section{MATERIALS AND METHOD}

The study used male Wistar newborn and adult rats aged 8-10 weeks. The animals were kept at a constant temperature of about $22^{\circ} \mathrm{C}$ and $12 \mathrm{~h}$ artificial light day/night cycle: $12 \mathrm{~h} / 12 \mathrm{~h}$ (light from 07:00 - 19:00). Throughout the experiment, the animals had free access to water and standard diet.

The experiment was approved by the local Bioethics Committee of the Silesian Medical University (Consent No. 66 of 11 December 2007).

\section{Performance of the CNS lesion $[10,11]$}

The male newborn rats were divided into 2 groups:

Group I (Control). The animals received zimelidine hydrochloride at a dose of $10 \mathrm{mg} / \mathrm{kg}$ b.w. s.c. in the volume of $1.0 \mathrm{ml} / \mathrm{kg}$ b.w., and after 30 minutes, $1.0 \mathrm{ml} / \mathrm{kg}$ b.w., s.c. of $0.9 \% \mathrm{NaCl}$ solution on day 1 and day 3 of life.

Group II (DSP-4). The animals were given zimelidine hydrochloride at a dose of $10 \mathrm{mg} / \mathrm{kg}$ b.w. s.c. in the volume of $1.0 \mathrm{ml} / \mathrm{kg}$ b.w., and after $30 \mathrm{~min}, \mathrm{DSP}-4$ at a dose of $50 \mathrm{mg} /$ $\mathrm{kg}$ b.w. s.c on day 1 and day 3 of life.

Behavioural tests aimed to assess the reactivity of the central $5-\mathrm{HT}_{3}$ receptors were performed in adult 8-10 week animals, using a selective antagonist of THE 5- $\mathrm{HT}_{3}$ receptor (ondansetron). The receptor ligand doses were determined based on own experience and literature data. The behavioural tests were conducted from 08:00 - 15:00; the respective groups consisted of 8-10 animals.

Assessment of the analgesic effect of ondansetron in models of persistent pain: writhing test - visceral pain model induced by a chemical stimulus [12]. According to the method, $24 \mathrm{~h}$ before the experiment, rats were deprived of access to food. On the day of the test, the animals were placed individually in glass cages of $400 \times 300 \times 200 \mathrm{~mm}$, and an ethacrynic acid solution, prepared in the ratio of $3 / 47$ weight parts of ethanol/ / water, was injected i.p. at a dose of $3.0 \mathrm{mg} / 1.0 \mathrm{~mL} / / 100 \mathrm{~g}$. The solution was prepared ex tempore. 10 min after the acid administration, observation was started and the number of writhing episodes was counted. In the literature, these episodes $[8,9]$ have been defined as assuming a characteristic flat body posture with a simultaneous lateral rotation of the spine and stretching of the hind paws, the so-called writhing syndrome. The episodes were counted for $60 \mathrm{~min}$ at 10 -min intervals $(10-20,20-30,30-40,40-50$, 50-60 min), starting from intraperitoneal injection of the irritant (ethacrynic acid). Next, for each time interval the mean value was calculated for each study group (control, DSP-4).

The writhing test was performed in the same way after administration of ondansetron (1.0mg/ $\mathrm{kg}$ b.w., i.p.) at doses as above in the control group, and in the rats with central noradrenergic lesions. Ondansetron was injected $30 \mathrm{~min}$ prior to the administration of ethacrynic acid.

Based on the results, the percentage of inhibitions of writhing episodes was calculated according to the formula:

$100 \times \mathrm{B}$

$\%$ of inhibitions $=100$

$$
\text { A }
$$

where $\mathrm{A}$ is the mean number of writhing episodes without the administration of the analgesic, calculated for the relevant time interval, whereas B - the mean number of writhing episodes in the respective time interval after administration of analgesic (separately for each rat)

Formalin test - the 'inflammatory' pain model induced by a chemical stimulus [13]. The rats were placed singly in glass cages $(400 \times 300 \times 200 \mathrm{~mm})$ and both groups received ondansetron (1.0 mg/kg b.w., i.p.). Next, after $30 \mathrm{~min}$, the animals received $50 \mu \mathrm{l}$ of $5 \%$ formalin solution in the right paw pad. After another $5 \mathrm{~min}$, the intensity of pain reaction was assessed for $70 \mathrm{~min}$ at $5 \mathrm{~min}$ intervals. Assessment was according to the following scale:

- 0 - lack of reaction;

- 1 - the animal's paw remains on the ground, but body weight shifts to the remaining three paws;

- 2 - the paw is elevated above the ground, but body weight rests on the other three paws;

- 3 - the animal licks the raised paw, and the body weight shifts to the remaining three paws.

\section{RESULTS}

The analgesic effect of ondansetron (1.0 mg/kg b.w., i.p.) in the writhing tests was weak and of short duration. After drug administration, no significant differences in the degree of analgesia were noted between the study groups (Fig. 1).

Formalin test. Pain intensity score after ondansetron injection (1.0 mg/kg b.w., i.p) was $2-3$ points and did not differ significantly between the study groups (Fig. 2). 


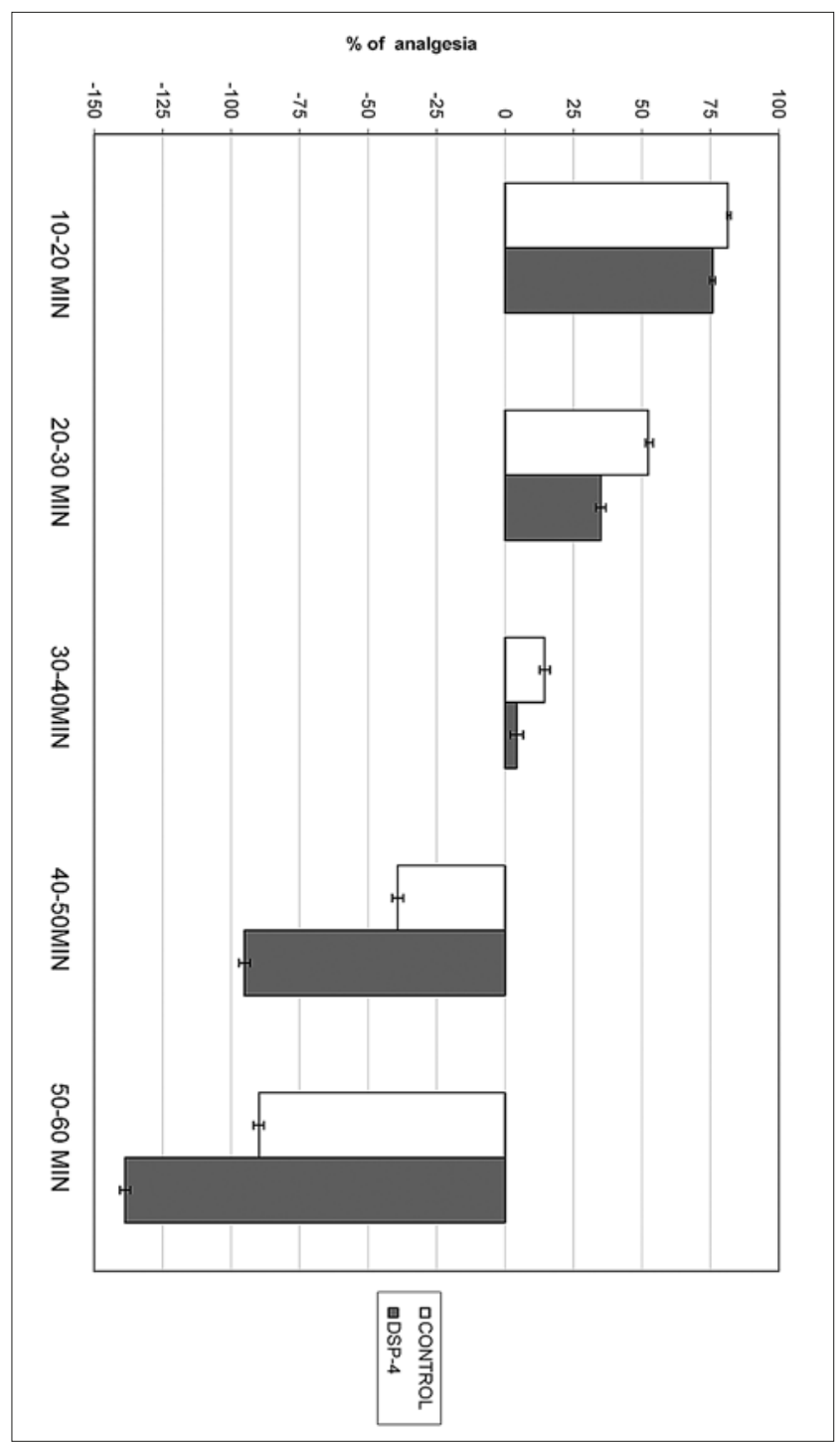

Figure 1. Effect of DSP-4 lesion on analgesia after ondansetron $(1.0 \mathrm{mg} / \mathrm{kg}$ b.w. i.p.) in the writhing test in rats $(\bar{x} \pm \mathrm{SEM} ; \mathrm{n}=10)$

\section{DISCUSSION}

Behavioural studies conducted in the last decade have shown that the administration of 5- $\mathrm{HT}_{3}$ receptor ligands to animals do not cause significant changes in their behaviour. However, these compounds modify the behavioural effects of other substances tested in the animal models of anxiety, psychoses and drug addictions $[14,15,16,17,18,19]$. Nevertheless, despite many years of research, the role of $5-\mathrm{HT}_{3}$ receptors in the perception of pain has not been clearly established, and in the majority of available studies the $5-\mathrm{HT}_{3}$ ligands were applied locally (intrathecally).

Glaum et al. [20] showed that the intrathecal (i.t.) administration of the selective agonist of $5-\mathrm{HT}_{3}$ receptors, 2-methyl-5-HT, in rats had a similar analgesic effect to 5-HT in the tail immersion test, and slightly weaker than 5-HT in the hot-plate test. Previous application of selective antagonists of the $5-\mathrm{HT}_{3}$ receptor abolished the antinociceptive effect of both 5-HT and 2-methyl-5-HT. Similar results were reported by Sasaki et al. [21] in the formalin test. The analgesic effect of $5-\mathrm{HT}_{3}$ receptor stimulation in the

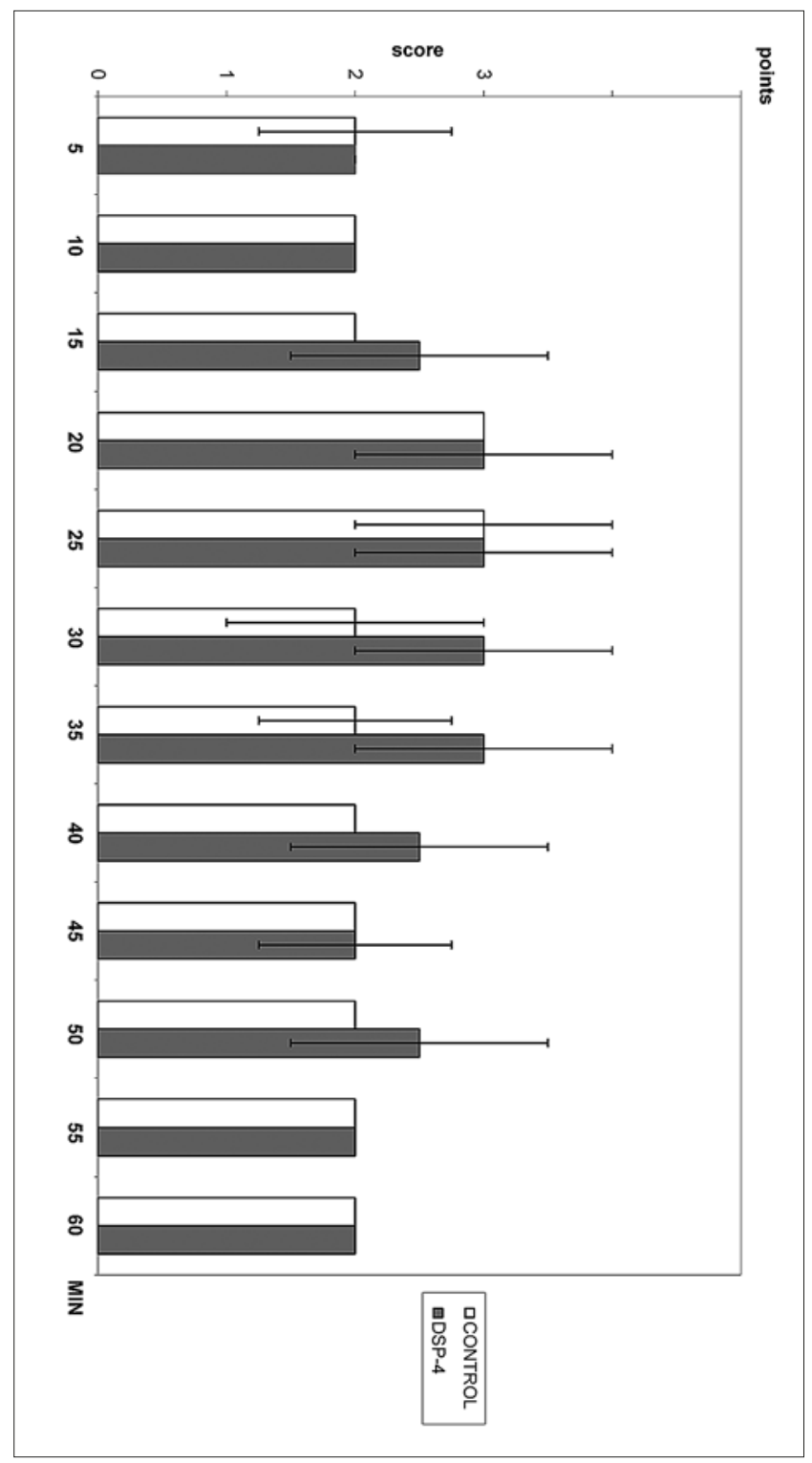

Figure 2. Effect of DSP-4 lesion on analgesia after ondansetron $(1.0 \mathrm{mg} / \mathrm{kg}$ b.w., i.p.) in the formalin test in rats $(\bar{x} \pm S E M ; n=10)$

dorsal horn of the spinal cord has also been confirmed in electrophysiological studies. Peng et al. [22, 23] found that the response of the posterior horn neurons of the spinal cord to pain was inhibited by stimulation of the periaqueductal grey. However, the intrathecal injection of 5-HT3 receptor antagonists to animals blocked this effect, which indicated the antinociceptive activation of this subtype of serotonin receptor at the spinal cord level. On the other hand, according to Xiao et al. [24], the 5-HT3 serotoninergic receptor is not involved in the antinociceptive effect of 5-HT. These researchers found no effect of the 5 -HT3 receptor antagonist injected into the spinal cord on the antinociceptive action of 5-HT. Paradoxically, other studies $[25,26,27]$ revealed that the $5-\mathrm{HT}_{3}$ receptor agonists enhanced pain response.

Zeitz et al. [25] examined pain response in knock-out mice deprived of a gene encoding the $5-\mathrm{HT}_{3} \mathrm{R}$-A subunit in a few models of acute and chronic pain. They found that in the mutated animals the response to acute pain was similar to that in healthy animals. However, in the model of chronic pain, lack of functionally active $5-\mathrm{HT}_{3}$ receptor attenuated 
the perception of pain. In turn, Giordano et al. [26] used a few antagonists of 5- $\mathrm{HT}_{3}$ receptors (ICS-205-930, MDL-7222 and GR-38032F) subcutaneously, and found that these substances had no analgesic effect in the models of pain induced by thermal or mechanical stimuli, but relieved chronic pain induced by thermal stimulus. Similar findings were reported by Sufka et al. [27] who observed that ondansetron applied locally prevented the perception of pain caused by the injection of 5-HT to the animal paw.

In another study, paroxetine, a selective serotonin reuptake inhibitor (SSRI), exerted an analgesic effect similar to that of morphine in the writhing test in mice. This effect was abolished by previous administration of ondansetron $\left(5-\mathrm{HT}_{3}\right.$ receptor antagonists), which may indicate the involvement of spinal $5-\mathrm{HT}_{3}$ receptors in the modulation of pain perception [28].

Taking into account the above results, it seems justified that apart from typical analgesics, pain therapy should also employ substances which do not have an obvious analgesic effect, such as glycocorticosteroids [29], N-methyl-D-asparaginian (NMDA) receptor antagonists [30], endocanabinoids [31], anticonvulsants [32] and antidepression drugs [33], allowing pharmacological modulation of effects of analgesic drugs in the treatment of pain.

Despite the low specificity of the writhing test used in the presented study, its considerable sensitivity allows determination of the analgesic effect of both opioids and drugs with a weaker analgesic effect. Therefore, the writhing test can be used in the screening of various compounds for their potential antinociceptive action. It is believed that the behaviour of animals after intraperitoneal injection of etacrynic acid is mainly of a reflex nature, although it cannot be excluded that the visceral peritoneum also receives somatic innervation [34].

The injection of formalin into the rat paw causes a two-phase behavioural response. The first phase lasts approximately $3 \mathrm{~min}$ and is caused by direct nociceptor stimulation, whereas the other phase, appearing after 20-30 min of exposure to the irritant, is an inflammatory response [34]. Some authors postulate that the second phase of the formalin test also involves central mechanisms, triggered by neuronal stimulation in the first phase, although this view is not widely accepted $[34,35]$.

The analgesic effect of ondansetron found in the currentr study in the writhing test and formalin assay was weak and of short duration. The administration of this compound did not cause any significant differences in analgesia intensity between the groups of rats studied.

\section{CONCLUSIONS}

Damage to the central noradrenergic system in the early period of individual development does not alter the antinociceptive effects of the serotoninergic 5- $\mathrm{HT}_{3}$ receptor antagonist, ondansetron, in the persistent pain model.

\section{REFERENCES}

1.McAllister-Williams RH, Ferreir IN, Young AH. Mood and neuropsychological function in depression: the role of corticosteroids and serotonin. Psychol Med. 1998; 28: 573-584.
2. Van de Kar LD. Neuroendocrine pharmacology of serotonergic (5-HT) neurons. Ann Rev Pharmacol Toxicol. 1991; 31: 289-320.

3. Fuller RW. Serotonin receptors and neuroendocrine responses. Neuropsychopharmacol. 1990; 3: 495-502.

4. Tison F, Normand E, Jaber M, Aubert I, Bloch B. Aromatic L-amino-acid decarboxylase (DOPA decarboxylase) gene expression in dopaminergic and serotoninergic cells of the rat brainstem. Neurosci Lett. 1991; 127: 203-206.

5. Cowen PJ. Cortisol, serotonin and depression: All stressed out? Brit J Psychiatry. 2002; 180: 99-100.

6. Bauer MS, Frazer A. Mood disorders. In A. Frazer, PB Molinoff A Winokur Biological basis of brain function and disease. New York: Raven, 1994.

7. Strickland PL, Deakin JF, Percival C, Dixon J, Gater RA, Goldberg DP. Biosocial origins of depression in the community. Interactions between social adversity, cortisol and serotonin neurotransmission. Brit J Psychiatry. 2002; 180: 168-173.

8. Mann JJ, McBride PA, Brown RP i wsp. Relationship between central and peripheral serotonin indexes in depressed and suicidal psychiatric inpatients. Arch Gen Psychiatry. 1992; 49: 442-446.

9. Roggenbach J, Muller-Oerlinghausen B, Franke L, Uebelhack R, Blank $\mathrm{S}$, Ahrens B. Peripheral serotonergic markers in acutely suicidal patients. 1. Comparison of serotonergic platelet measures between suicidal individuals, nonsuicidal patients with major depression and healthy subjects. J Neural Transm. 2007; 114: 479-87.

10. Jaim-Etcheverry G. 2-chloroethylamines (DSP-4 and xylamine). Toxic action on noradrenergic neurons. W: Hight selective neurotoxins. Basic and clinical application. Kostrzewa RM - Human Press, Totowa, New Jersey 1998; 131-140.

11. Dooley DJ, Moglinicka E, Dolini-Stula A, Waechter F, Truog A, Wood J. Functional supersensitivity to adrenergic agonist in the rat after DSP-4, a selective noradrenergic neurotoxin. Psychopharmacol. 1983; 81: 1-5.

12. Korzeniewska-Rybicka I, Płazik A. Analgesic effect of antidepressant drugs. Pharmacol Biochem Behav 1998; 111: 503-508.

13. Acton J, McKenna JE, Melzack R. Amitriptiline products analgesia in the formalin pain test. Exp Neurol. 1992; 117: 94-96.

14. Quednow BB, Westheide J, Kuhn KU et all. Normal prepulse In hibition and habituation of acoustic startle response in suicidal depressive patients without psychotic symptoms. J Affect Disord. 2006; 92: 299-303.

15. Loomer HP, Saunders JC, Kline NS. A clinical and pharmacodynamic evaluation of Iproniazid as a psychic energizer. Psychiatr Res Rep Amer Psychiatr Ass. 1957; 8: 129-141.

16. Dietz BM, Mahady GB, Pauli GF, Farnsworth NR. Valerian extract and valerenic acid are partial agonists of the 5-HT5a receptor in vitro. Mol Brain Res. 2005; 138:191-7.

17. Bespalov A, Dumpis M, Piotrovsky L, Zvartau E. Excitatory amino acid receptor antagonist kynurenic acid attenuates rewarding potential of morphine. Eur J Pharmacol. 1994; 264: 233-239.

18. Wiborg O, Sanchez C. Escitalopram: a comparative in vitro study of 5 -HT uptake inhibition and binding in a COS-1 cell line expressing human 5-HT transporter. Eur Neuropsychopharmacol. 2002; 12: 229.

19. Archer T, Jonsson G, Minor BG, Post C. Noeadrenergic-serotoninergic interactions and nociception in the rat. Eur J Pharmacol. 1986; 120: 295-307.

20. Glaum SR, Proudfit HK, Anderson EG. 5-HT3 receptors modulate spinal nociceptive reflexes. Brain Res. 1990; 510: 12-16.

21. Sasaki M, Ishozaki K, Obata H. Goto F. Effects of 5-HT2 and 5-HT3 receptors onmodulation of nociceptive transmission in rat spinal cord, according to the formalin test. Eur J Pharmacol. 2001; 424: 45-52.

22. Peng YB, Wu J, Willis WD, Kenshalo DR. GABA(A) and 5-HT(3) receptors are involved in dorsal root reflexes: possible role in periaqueductal gray decending inhibition. J Neurophysiol. 2001; 86: 49-58.

23. Peng YB, Lin Q, Willis WD. The role of 5-HT3 receptors in periaqueductal gray-induced inhibition of nociceptive dorsal horn neurons in rats. J Pharmacol Exp Ther. 1996; 276: 116-124.

24. Xiao DQ, Zhu JX, Tang JS, Jia H. 5-hydroxytryptamine 1A (5-HT1A) but not 5-HT3 receptor is involved in mediating the nucleus submedius 5-HT-evoked anti- nociception in the rat. Brain Res. 2005; 1046: 38-44.

25.Zeitz KP, Guy N, Malmberg AB, Dirajlal S, Martin WJ, Sun L, Bonhaus DW, Stucky CL, Julius D, Basbaum AI. The 5-HT3 subtype of serotonin receptor contributes to nociceptive processing via a novel subset of myelinated and unmyelinated nociceptors. J Neurosci. 2002; 22: 10101019.

26. Giordano J, Dyche J. Differential analgesic actions of serotonin 5-HT3 receptor antagonists in the mouse. Neuropharamcology 1989; 28: 423-427. 
27. Sufka KJ, Schomburg FM, Giordano J. Receptor mediation of 5-HTinduced inflammation and nociception in rats. Pharmacol Biochem Behav. 1992; 41: 53-56.

28. Kesim M, Duman EN, Kadioglu M, Yaris E, Kalyoncu NI, Erciyes N. The different roles of 5-HT2 and 5-HT3 receptors on antinociceptive effect of paroxetine in chemical stimuli in mice. J Pharmacol Sci. 2005; 97: 61-66.

29. McEwen BS, Kalia M. The role of corticosteroids and stress in chronic pain conditions. Metabolism. 2010; 59: 9-15.

30. Bleakman D, Alt A, Nisenbaum ES. Glutamate receptors and pain. Seminars in Cell \& Developmental Biology 2006; 17: 592-604.

31. Guindon J, Hohmann AG. The Endocannabinoid System and Pain CNS Neurol Disord Drug Targets. 2009; 8: 403-421.
32. Johannessen Landmark C. Antiepileptic drugs in non-epilepsy disorders: relations between mechanisms of action and clinical efficacy. CNS Drugs 2008; 22: 27-47.

33. Sawynok J, Esser MJ, Reid AR. Antidepressants as analgesics: an overview of central and peripheral mechanisms of action. J Psychiatry Neurosci. 2001; 26: 21-29.

34. Le Bars D, Gozariu M, Cadden SW. Animal models of nociception. Pharmacol Rev. 2001; 53: 597-652.

35. Coderre TJ, Fundytus ME, McKenna JE, Dalal S, Melzack R. The formalin test: a validation of the weighted-scores method of behavioural pain rating. Pain 1995; 54: 43-50. 